\title{
Looking back and looking forward-adapting to extreme weather events in municipalities in western Norway
}

\author{
Helene Amundsen ${ }^{1} \cdot$ Halvor Dannevig ${ }^{2,3}$ (D)
}

Received: 24 January 2020 / Accepted: 10 September 2021 / Published online: 23 October 2021

(c) The Author(s) 2021, corrected publication 2022

\begin{abstract}
In October 2014, an extreme precipitation event hit western Norway, which caused flooding, landslides and severe damage to infrastructure and houses. Climate model projections for western Norway show that heavy precipitation events, such as the one in 2014, will increase in frequency and intensity in the future. This paper discusses barriers to proactive adaptation to high-impact weather events in two municipalities in western Norway. Interviews were conducted with representatives from municipalities in this region to understand the adaptation measures the municipalities had implemented after this event and the barriers to proactive adaptation to extreme events in the future. We found that the key barriers to proactive adaptation are lack of resources, lack of knowledge and lack of willingness to adapt. The magnitude of the event meant that only a few of the informants expected the municipality to be hit by such an extreme event again in the near future, and as such, they did not see a need for major adaptation measures. Further, some assumed that the municipality was sufficiently protected because their areas either were not directly affected or were secured after the event. Finally, some interviewees assumed that it is not possible to adapt to such high-magnitude events.
\end{abstract}

Keywords Adaptation $\cdot$ Extreme weather events $\cdot$ Western Norway $\cdot$ Municipality $\cdot$ Barriers

\section{Introduction}

In October 2014, an extreme precipitation event hit western Norway, causing flooding and landslides (Dannevig et al. 2016; Langsholt et al. 2015; Valved and Olsen 2014). The event resulted in severe damage to infrastructure and houses. In some areas, this was the type of flood that only occurs every 200 years, and as such, it was unprecedented in the inhabitants' memory. Climate model projections for western Norway show that heavy precipitation events, such as the

Communicated by Shannon Hagerman.

Halvor Dannevig

hda@vestforsk.no

Helene Amundsen

heleamu@gmail.com

1 CICERO Center for International Climate Research, Gaustadalleen 21, 0349 Oslo, Norway

2 Norwegian Research Centre on Sustainable Climate Change Adaptation, Western Norway Research Institute, P.O. Box 183, Sogndal, Norway

3 P.O. Box. 163, 6851 Sogndal, Norway one in 2014, will increase in frequency and intensity and flood levels are projected to increase by $40 \%$ by the end of the century (Hanssen-Bauer et al. 2015; Whan et al. 2020). Despite available climate projections indicating the risk of such events (e.g. Hanssen-Bauer et al. 2009), the current events found the local actors unprepared.

It has long been established that the consequences of climate change will require adaptation (e.g. IPCC 2014a, 2014b). Recent estimates of flood risk show that the need for adaptation will increase in the future, both in industrialised and developing countries (Willner et al. 2018). Furthermore, the cost of river flooding will increase significantly at the global level with respect to direct economic cost, human losses and welfare (Dottori et al. 2018).

Adaptation may take place after an event, such as flooding, has occurred, and this type of adaptation is referred to as reactive or autonomous (IPCC 2012). Alternatively, adaptation may take place in anticipation of a future change and is referred to as proactive or planned adaptation (op cit.; Füssel 2007). The benefit of proactive adaptation is the possibility to reduce the impact of the change before it occurs, and as such, lessen damage to humans and society and reduce economic costs. Adaptation must be flexible so 
that it can both cater to the local context within which it is implemented and change with changing conditions, for example, with advancing (scientific) knowledge about the extent of climate change impacts.

Since the publication of the Official Norwegian Report on climate change adaptation (MoE 2010), significant changes have been made to how adaptation is organised in Norway, with a stronger role taken by the state, including making available the regional climate change profiles for every region in Norway and giving clearer responsibilities to municipalities. It is now mandated in regulations that municipalities check coverage of the climate change impact on flood levels and storm water surges; in other words, climate risks, in risk and vulnerability assessments, submitted along with zoning and building plans. This means that municipalities can be held legally responsible for not taking climate risks into concern when approving zoning plans or construction permits, and that a 'fear' regress claims from insurance companies could act as an additional incentive for adaptation. Other adaptive measures need to be 'voluntarily' implemented by the municipality. Several studies have found that proactive municipal adaptation measures outside those mentioned above have been largely ad hoc and depend on engaged individual(s) to drive the adaptation agenda (Aall et al. 2018; Dannevig et al. 2013). In addition, most zoning and building plans are made by private developers (Falleth and Hanssen 2012; Junker 2015), which means that the climate risk assessments included in them are outsourced. A Canadian study found that there has been an outsourcing of local adaptation plans due to a lack of resources, which may lead to local solutions that are not directly linked to the local context and rely on technical measures (Crabbé and Robin 2006). Municipal adaptation plans are still rare in Norway, but the new planning guidelines for mitigation, energy and adaptation planning from 2018 require the inclusion of adaptation in municipal climate and energy plans. In adaptation planning, the regional climate profiles developed by the Norwegian Climate Service Centre should provide the knowledge base.

Flood protection is typically a key prioritisation in local adaptation strategies across Europe (Aguiar et al. 2018), and this has also been found to be the case for Norwegian municipalities, where adaptation activities have mainly been concerned with responding to extreme precipitation or flooding (Aall et al. 2018; Amundsen et al. 2010) and preparing for extreme events, for example, by putting in place avalanche protection (Hovelsrud et al. 2010).

Factors that support proactive adaptation include 'the occurrence of previous strong focusing events' (IPCC 2012, p. 308). In Norwegian studies of municipalities, experience with extreme events has also been found to be an important factor for implementation of adaptation measures that relate to the projected climate change (Amundsen et al. 2010;
Dannevig et al. 2013). Norwegian municipalities that have experienced extreme events are more likely to discuss adaptation to future extreme events and to consider and implement adaptation measures (Amundsen et al. 2010; Dannevig et al. 2013). New knowledge of risk may also emerge as part of the planning and development process of a new area or housing development; according to the Norwegian Planning and Building Act, evaluation of risk of natural hazards should be undertaken in advance of new developments. In contrast, the last few years have seen the emergence of several adaptation networks that seem to boost collaboration across scales and sectors in the government and increase competence and inspire solutions for adaptation in municipalities (Hauge et al. 2018; Flyen et al. 2018). Still, municipalities are struggling with proactive adaptation due to a lack of capacity, resources and knowledge of adaptation measures (Aall et al. 2018).

This paper presents how an extreme event was experienced differently in two municipalities in western Norway and the adaptations in place after the event. Furthermore, it identifies barriers to proactive adaptation to extreme events and discusses how these may be overcome.

\section{Barriers to adaptation in the municipal context}

There are several known barriers to adaptation that are well covered in the literature; these include lack of resources, knowledge and information; low perception of the need for and motivation to adapt; prioritising tasks other than adaptation; lack of regulation and guidelines; and lack of clear delegation of responsibility. As stated by the IPCC, a 'range of biophysical, institutional, financial, social, and cultural factors constrain the planning and implementation of adaptation options and potentially reduce their effectiveness' (Klein et al. 2014, p. 902). These factors interact, and '[1]imits to adaptation can emerge as a result of the interactions among climate change and biophysical and socioeconomic constraints' (Klein et al. 2014, p. 902). Thus, the common understanding of the difference between barriers and limitations is that barriers pertain to obstacles that can be overcome, whereas limits are insurmountable (Eisenack et al. 2014). A literature review of the barriers to adaptation found that barriers differ with context and are linked to other processes (Biesbroek et al. 2013). Moser and Ekstrom (2010) argued that barriers emerge at all stages of adaptation processes, and Eisenack and colleagues (2014) highlighted the need to address both the interdependence and dynamics of barriers. Burch (2010) focussed on transforming barriers into enablers of action and argued that it is necessary with 'an explicitly articulated high-level directive, leadership that stimulates an organisational culture of innovation 
and collaboration and the "institutionalisation" of climate change response measures within standard operating procedures' (p. 287). Barriers to adaptation typically fall into three or four broader categories. In the context of local governments, the following categories of barriers to adaptation have been highlighted: 'regulatory, structural, behavioural, cultural, and contextual factors', as well as capacity (Burch 2010, p. 291). For the purpose of this study, we group barriers into lack of local knowledge, lack of resources and lack of willingness to adapt. These are slightly more focussed than the categories by Burch (2010), but they still capture some of the same mechanisms, as illustrated below. While technical and biophysical barriers have also been identified in the literature, they have not emerged as salient in a Norwegian context, including the study that the present article is based on.

Lack of knowledge is still a barrier to adaptation, and a study of Norwegian municipalities identified the key barriers as 'unfamiliarity with existing data on climate change; lack of concrete data and lack of local expertise for dealing with effects of climate change' (Amundsen et al. 2010, p. 2084). A more recent review found that, while this factor is still a barrier, it is no longer as significant as previously found (Aall et al. 2018). In the case of Norway, the challenges in relation to climate change knowledge now pertain to tailoring existing scientific knowledge with local knowledge and the needs of the municipalities, as well as the capacity by municipal planners to use available local knowledge (Aall et al. 2018; Dannevig and Aall 2015). Thus, this barrier consists both of lack of locally relevant knowledge, i.e. scientific climate knowledge tailored or co-produced to the specific local context, and local knowledge, which is knowledge possessed by local stakeholders and other local residents (Klenk et al. 2017). These two forms of knowledge should ideally be merged by processes of co-production in order to be actionable and relevant to users (i.e. Dilling and Lemos 2011; Clark et al. 2016; Dannevig et al. 2019). It is widely recognised that processes of co-production that integrate scientific knowledge with local knowledge are needed for planned adaptation (Klenk et al. 2017; Dannevig and Aall 2015; Kirchhoff et al. 2013).

Lack of resources is a recurring barrier in multiple studies and occurs in all phases of the adaptation process (Moser and Ekstrom 2010). Adaptation requires fiscal, technical and administrative resources, and if any of these are lacking, it prevents adaptation from happening. Lack of resources also includes competing priorities in the planning processes (Measham et al. 2011) and lack of funding and prioritisation of limited local government funds (Burch 2010; Porter et al. 2015):

If our LA [local authority] respondents are keen to have more information about the economic costs of severe weather, it is not simply because their LAs need 'to account for the full costs and benefits of all adaptation options' (DEFRA, 2013c: 2); information about costs is a crucial resource for them in the internal battles within LAs to secure the resources and institutional license to do adaptation. (Porter et al. 2015, p. 421)

The administrative capacity in municipalities to assess the need for adaptation is also found to be a barrier to adaptation in Norway (Aall et al. 2018). Insurance could also be a factor influencing municipal priorities. As mentioned above could municipalities be liable for regress claims from insurance companies if they have allowed constructions of buildings and infrastructure in areas that are unsafe according to the natural hazard risk criteria in the building and spatial planning regulation, ${ }^{1}$ should the buildings later be damaged by natural hazards or inundation.

Over time, there has been an increased focus on the social and cultural barriers to adaptation in terms of how these affect the (lack of) willingness to adapt. For instance, Adger et al. $(2009,2011)$ discussed the social barriers to climate change, such as the values and knowledge people have, the perception of risk and the places, and values at risk of being lost (see also Tschakert et al. 2017). Perceptions of risks have implications for adaptation, and lack of perception of risk can act as a barrier for both adaptation and mitigation (Gifford et al. 2011). Understanding who and what is at risk is important. It has both material and non-material dimensions. Dannevig and Hovelsrud (2016) showed how values and worldviews influence how different actors perceive climate change risks and the need to adapt. They found that, in the same community, municipal planners, inclined to a hierarchical way of life, were more concerned about adaptation to climate change compared with farmers and fishermen, who displayed a more individualistic way of life.

Given that knowledge about climate risk exists and is available to local decision makers, the question is what it takes for proactive adaptation to such extreme events to be carried out. If no proactive adaptation takes place, we need to ask what barriers prevent proactive adaptation. Thus, for the municipal context of relevance to this paper, key barriers to adaptation pertain to lack of resources, lack of knowledge, and lack of willingness to adapt (e.g. Aall et al. 2018; Burch 2010; Dannevig and Hovelsrud 2016; Measham et al. 2011; Porter et al. 2015).

\footnotetext{
1 The regulation name is TEK 17 and it is issued by the Norwegian Building Authority.
} 
Fig. 1 Map of the case study area

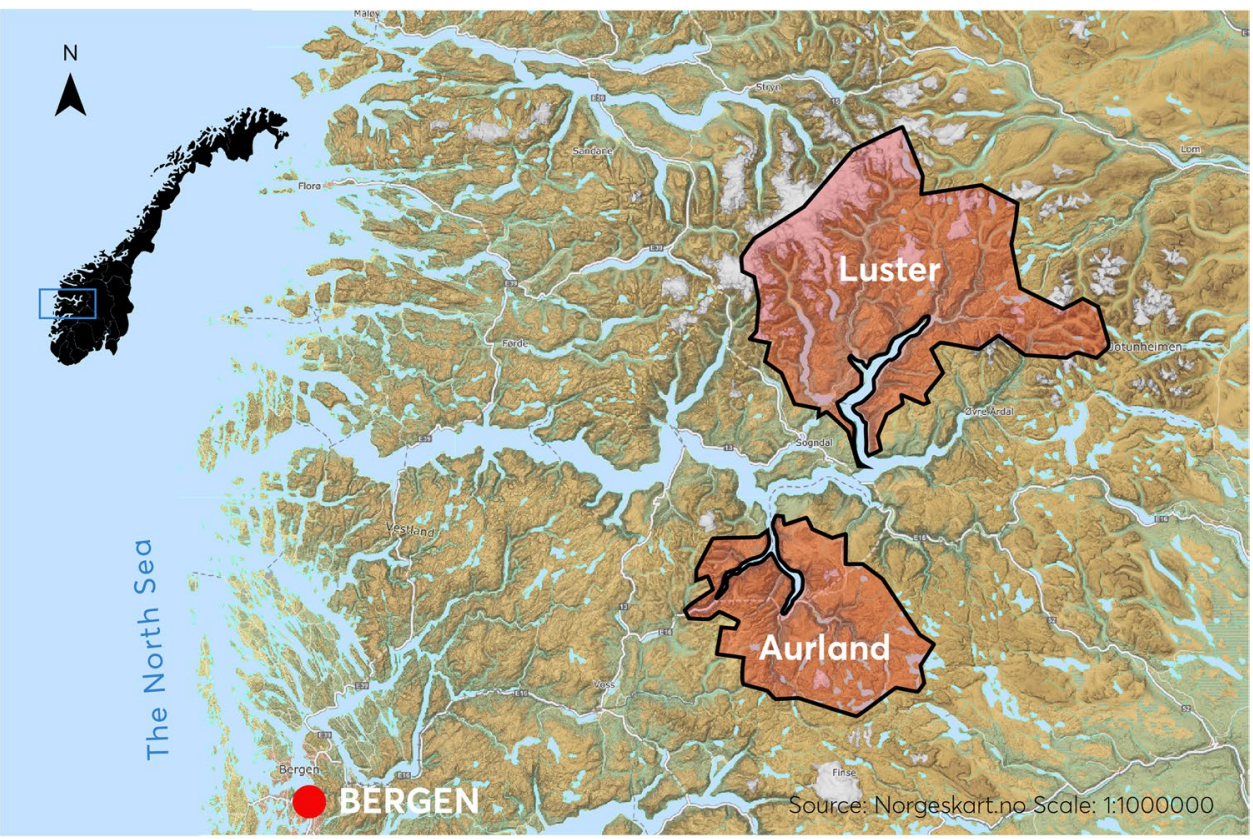

\section{Methods}

In this study, we investigate adaptation measures introduced after an unprecedented extreme event that hit western Norway in October 2014. For this study, two municipalities were selected according to a set of criteria to allow for comparison between the two cases. We selected two municipalities located in Sogn and Fjordane County ${ }^{2}$ in western Norway, which are situated relatively close to each other (see Fig. 1). The municipalities were further selected based on similarities regarding population size and main business and industry sectors. We selected one municipality that experienced severe damage from the extreme event and one municipality that was less affected. These criteria led to the selection of Luster and Aurland municipalities. Both have large hydropower installations within their areas, and tourism is important for the local economy.

The methods employed included document analyses and qualitative interviews. Eight semi-structured interviews were conducted with six informants, which includes the following: representatives from two municipalities (informants 1 , 2, 3, 4 and 6) in the region, and with one representative from Statkraft, a major hydropower producer in the area (informant 5), in October 2017. Two of the municipal officers were also interviewed in 2016 (also reported in Dannevig et al. 2016; informants 1 and 6). The interviewees in the municipalities were representatives from the administration and covered areas of spatial planning, road maintenance and

2 On 1 January 2020, Sogn and Fjordane County merged with Hordaland County to form Vestland County. other technical aspects (informants 2, 3, 4 and 6), as well as emergency preparedness (informant 1 ). For the purpose of this study, we were interested in spatial planning, emergency preparedness and practical implications of the events, and these six informants represent these areas in the two municipalities. The foci of the interviews were to understand how the municipalities responded after this event and what adaptation measures were put in place. The interviews also covered whether and how high-impact events were included in the long-term planning of the municipalities. Further, the interviews covered the barriers to adaptation, and specifically barriers to proactive adaptation to extreme events in the future. We also asked whether risk perception concerning extreme events had changed after the event.

The documents studied include municipal plans $(n=4)$, flood zone mapping reports $(n=2)$, minutes from event debrief meetings $(n=2)$ and the various reports published after the events. These reports include the reports of the Norwegian Meteorological Institute (Valved and Olsen 2014) and the Directorate of Water and Energy (NVE) (Langsholt et al. 2015), in addition to the reports commissioned by the municipalities (Multiconsult 2015, 2018; Norconsult 2016; Norwegian Geotechnical Institute [NGI] 2016, 2017). The documents were reviewed for event descriptions, quantifications of damages, changes and revisions in planning documents, adherence to regulations in zoning plans and existing knowledge about flood risk prior to the event. The analyses employ both the interviews and the written documents to form an understanding of the processes and outcomes relating to the event, measures implemented and learning after the event and the barriers to adaptation that were expressed. 


\section{Event description}

From 26 to 29 October 2014, an unusual amount of rain fell in western Norway, a region that already tends to be very wet, particularly in the autumn season. Since this was late in the autumn, there was snow in the mountains that melted during these extraordinarily rainy days. The threshold for water supply over 3 days as a percentage of the maximum daily precipitation for a 200 -year period was also crossed in the watersheds in the case municipalities (based on interpolated data on snowmelt and precipitation from $\mathrm{NVE}^{3}$ ). The heavy rainfall in combination with the snowmelt created extreme flood conditions in several rivers, with record high levels (Langsholt et al. 2015). Some of these led to severe damage, with houses being swept into the river, roads and bridges annihilated and hundreds of people evacuated under dramatic circumstances. There were no casualties.

\section{The event in Flåm valley, Aurland Municipality}

The Flåm valley in Aurland Municipality was one of the most severely affected places during the flood event. A total of $230 \mathrm{~mm}$ of precipitation was recorded over 3 days, the largest amount recorded since 1900. The water flow instruments measured such large values that, according to an interviewee, the manager at the E-CO hydropower plant was notified that the measurements at Myrdal were faulty, but in reality, they were correct. An analysis by Norconsult (2016) indicates that this was the type of flood that occurs once in 200 years, called a 200-year flood according to NVE's categorisation. This was also seen in practice because houses outside the boundaries for 200-year floods were destroyed. National regulation mandates that flood risk zones are determined on the basis of flood levels that are reached once in every 200 year.

In Flåm, 13 houses were either swept into the river or destroyed by the flood, and 256 persons of a population of 400 were evacuated (Aurland Municipality 2015). According to informant 1 , the churchyard was partly eroded, as well as a nearby Neolithic burial site. This informant also testified to the unique and unexpectedly damaging power of the event. The local school was flooded and had to be closed, due to damage to the school building and to the road and bridge leading to the school. Village residents had trouble

\footnotetext{
$\overline{3}$ Retrieved from NVE's online water and climate geographic information system (GIS) portal: http://www.xgeo.no/index.html?p= fag $\& \mathrm{~m}=$ bmGeodataGraatone\% 3BMapLayer_gwb_qtt3d prrrx $\mathrm{m} 200 \& \mathrm{l}=\mathrm{en} \& \mathrm{~d}=1414450800000 \& \mathrm{e}=-16667 \% 7 \mathrm{C} 6737226 \% 7 \mathrm{C} 138$ $358 \% 7 \mathrm{C} 6813257$
}

accepting the school closure, with many afraid that it would not open again. It is a small school with only 40 pupils.

Several bridges and roads were destroyed. The municipality suffered losses amounting to 130 million NOK, and the railroads, county roads and hydropower installations had damages amounting to around 50 million NOK (Aurland Municipality 2015). The Flåm river is protected, but there are two older hydropower installations in the river, one larger magazine in the mountains and a small dam with a river power plant in the valley. The water level in the magazine was high because of the large amount of precipitation over several days and lack of capacity for reducing the flood level in the river. The catchment is steep and goes from 1700 to $0 \mathrm{~m}$ above sea level; hence, the water flow in the river responds rapidly to increased precipitation and snow melt.

Although there have been larger floods in the area, this flood was the most destructive in modern times. This was due to the high speed of the water, which again led to rapid erosion of the riverbanks. Therefore, some local informants characterised the event not as a flood but as a flood avalanche (or flash flood). Aurland municipality has several other large rivers, but in these rivers, there are large-scale hydropower plants. Therefore, there was no damaging flooding in these rivers. Aurlandsvangen (the municipal centre in Aurland) was not affected by the flood because of the regulated catchment. Here, E-CO was instrumental in securing Aurlandsvangen through managing the dam.

During the event, several systems for risk management did not function well, and according to informant 6 , it was 'sheer luck' that no lives were lost. There was a noted dissatisfaction with NVE, both during the event and during the restoration process. NVE was criticised for the lack of warning about the event and the knowledge level during the event. (Informant 1 claimed they sent people without experience with flooding to manage the crisis.)

\section{Planning and natural hazard risk assessment status for the Flåm valley at the time of the event}

The municipal spatial plan from 2009 designates most of the area in Flåmsdalen as 'mixed agricultural lands', but there are also some areas designated for housing. The only zoning plan in the area is for the school. The spatial plan requires a zoning plan for the construction of new buildings, which automatically triggers a need for flood and avalanche risk assessments. A flood map for Flåm valley was produced in 2009; this map designated a flood zone within the area that would be flooded by a 200 -year flood. Some buildings that were destroyed were in the flood zone, while some were outside it. The houses that were destroyed by the flood were all built before any spatial plan was devised and before there was regulation that mandated flood risk assessment prior to construction (Dannevig et al. 2016). The flood map was 
applied in building regulations to require that houses were built higher. Informant 2 noted that it was not a popular regulation because it made building more expensive, but the houses built under the regulations were not affected by the flood in 2014. According to the same interviewee, in hindsight, people saw the importance of establishing such regulations.

Aurland is a relatively wealthy municipality because of income from large hydropower installations. This has allowed Aurland municipality to invest in natural hazard mitigation efforts, which were well underway before the 2014 event. Aurland took part in a large research and development project for an early warning system for geological hazards, mainly larger landslides (see NGI 2017). However, this work did not assess the flood risk or consider protection of the houses and infrastructure that were already known to be exposed to a 200-year flood according to the flood zone maps. To avoid future floods, the mayor of the municipality has called for revoking the protection of the Flåm river so that it can be regulated with a larger magazine. Although the most salient benefit would be increased electricity production from a larger hydropower plant, the measure is still framed in the media as a climate change adaptation. ${ }^{4}$ So far, this initiative has been rejected by national authorities. Also worth noting is that calculation by a consultancy firm showed that, had there been available filling capacity at the time, the existing magazine in the Flåm catchment would have been sufficient to prevent a catastrophic flood (Multiconsult 2015).

\section{The event in Luster municipality}

In Luster municipality, according to informant 3, the event was a 'close call'. Like in Aurland, the largest catchments in Luster are developed with large hydropower plants. The main settlement in Luster municipality, Gaupne, was not severely affected by the event because the magazines could retain the water. Statkraft (the hydropower plant owner) noted, 'It was very lucky that the dams had room for the extra water'. One preventive measure that Statkraft takes to be able to mitigate floods is to refrain from having full reservoirs in the autumn. That is why they state that it is in the non-regulated rivers where floods are most likely to occur: 'In the specific situation in October 2014, regulated catchments were instrumental. However, we cannot guarantee that things will go well each time' (informant 5).

\footnotetext{
4 https://www.nrk.no/norge/vannkraft-sparer-oss-for-milliarder-iflomskader-1.13974135 (accessed 12.12.2019); https://www.nrk.no/ sognogfjordane/fryktar-for-framtida-til-flamsvassdraget-1.13264166 (accessed 12.12.2019).
}

Smaller side rivers in Gaupne flooded, and according to informants 3 and 4, a new housing development was nearly flooded. These informants noted that they only just managed to keep the buildings clear of water, and the water stopped just below the doorframes of some new houses.

\section{Planning and natural hazard risk assessment status for Luster municipality at the time of the event}

Two flood zone maps were developed by the NVE for the municipality in early 2000; they were developed for the main settlement of Gaupne and two hamlets further up the Jostedal valley. The maps show zones that are at risk of flooding from 10- to 200-year floods. The level for 200-year floods is used in determining new areas suitable for housing and buildings and is incorporated into the spatial plan. Because of these flood maps, there are also restrictions concerning building basements in houses, as noted by informant 3: 'Building basements in Gaupne has not been allowed for a very long time'. Still, the overall risk assessment in the municipality from 2014, before the event, did not identify flooding as a critical issue in the municipality (Luster Municipality 2014).

\section{Adaptation measures put in place after the event}

According to the interviews, we find that both municipalities put measures in place after the 2014 flood, including updated flood zone maps and planning regulations for new buildings. In accordance with previous research (Amundsen et al. 2010; Dannevig et al. 2013), the municipality that was the most affected by this event, Aurland, has introduced the most measures. The municipality commissioned the following measures: (i) a new flood zone assessment (Norconsult 2016), (ii) a report on measures to reduce the consequences of future floods with a focus on life and health (Multiconsult 2016) and (iii) an erosion risk assessment for the Flåm riverbanks (NGI 2016). The new flood zone maps were published in 2019 and included a 40\% per cent 'climate change increase' on flood levels for areas with homes. The flood maps are binding for all new buildings in Flåm. Where there is no erosion, the requirement is to build with a reinforced foundation and no basement. As an example, the new housing for employees at Fretheim hotel in Flåm will be built on stilts. A problem for most of the region is limited areas suitable for house building that are not flood prone. In addition, there is a question of protecting agricultural land from housing developments.

Since October 2014, there have been several new municipal zoning plans in the areas most affected by the flood event and resulting erosion and slides. As part of follow-ups of the mentioned landslide project (NGI 2017), the municipality 
has particularly invested significantly in additional measures for monitoring slides. This includes investment in a weather station and porewater pressure measuring. The municipality has also used a helicopter for ground mapping.

In Luster, the interviewees noted that the flood maps from NVE had been updated; as informant 3 stated, '[I] expect that they have made use of relevant information'. The main change in regulation since the flood in 2014 is that new houses are to be built at $3.5 \mathrm{~m}$ above sea level, representing an increase of $1.5 \mathrm{~m}$. The municipal centre, Gaupne, is mostly at $2 \mathrm{~m}$ above sea level. The new houses that only just avoided being flooded in 2014 had been built as the first of several stages of housing development. During the event, the Jostedøla river brought with it plenty of debris; this mass was used to heighten the ground level for the new houses.

In interviews in both Aurland and Luster, it was noted that the risk and vulnerability analyses would be revised. However, by January 2020, no revisions had been published in either municipality. Luster municipality has somewhat changed its practice when a large amount of rain is anticipated; in such a case, the municipality 'check[s] that everything works' (informant 4). This refers to, for example, controlling the functioning of draining systems. The municipality is responsible for $120 \mathrm{~km}$ of roads; about half the roads are gravel, and many of them are steep. If there are problems with these roads, masses will slide out, and this may create challenging situations. The municipality has not carried out other proactive adaptation measures besides raising the minimum height above sea level for construction of buildings.

\section{Barriers to adaptation in the two municipalities}

While no lives were lost during the flood, it caused immense damage. In hindsight, the damages could have been reduced if more measures to prevent floods or damages from floods had been in place prior to the event. In terms of physical barriers to adaptation, large hydroelectric dams in this region prevent or mitigate flooding in the largest catchments. Thus, a core challenge regarding flooding is related to protected catchments that cannot be developed; however, measures can and have been taken in these catchments to reduce the risk of future flooding. A larger physical barrier to adaptation lies with flooding from small and side rivers and streams. These are localised issues as there are many small rivers and streams and undertaking adaptation measures for all these tributaries is not possible. In the following, we are categorising the different non-physical barriers we identified (see Table 1 for an overview of these).

\section{Lack of locally relevant knowledge}

The municipalities are requesting local knowledge to prioritise between different parts of their municipalities. The state level provides the climate profiles, which include updated climate change projections for temperature, precipitation and floods for the county. To a certain degree, both Luster and Aurland found them useful; however, some informants (1, 3 and 6) also noted that they are too general. In this region, to a large degree, the consequences of a weather event are determined by topography. The variation is local, and regional prognosis is found to be of little value. One example given was the climate profile projections of a $20-30 \%$ increase in slides by 2100 ; registered events show that 'we are at this point now' (informant 1). Informant 1 argued that they need to know whether various places and villages are equally exposed, and the municipality needs knowledge on a detailed level to prioritise between places: 'If we perceive Flåm and Aurland to be equally exposed, we cannot prioritise between the two' (informant 1).

\section{Lack of resources}

In Aurland, it was noted in the interviews that there is political support for the need for measures; yet, it was also noted that, although significant changes to current plans were required after the flood event, extra support for spatial planning was not provided. However, the municipality supported attendance at courses to update planners and others on new knowledge. This is an example of prioritisation of resources in a municipality. Aurland has prioritised focussing on a large, unstable slope in the Flåm valley over spatial planning processes in the municipality; consequently, in line with this priority, it has established monitoring stations and early warning systems in the valley. None of the municipal informants mentioned liability for regress claims from insurance companies as a factor influencing motivation for carrying out adaptation measures.

\section{Lack of willingness to adapt}

Perceptions concerning the need to adapt are a clear barrier to proactive adaptation. As noted above, the 2014 flood was a major event, particularly in the Flåm valley, in which houses outside the 200-year flood zone were destroyed. Because of the large magnitude of the flooding, and its rarity (because of destruction of property outside of the 200 year flood zone), residents do not expect that a similar event will occur again; consequently, there is no perceived need for proactive adaptation beyond measures that are already in place, such as new zoning plans for the area and restoration of the river and damaged infrastructure. The lack of foresight that an event of such a magnitude would even be possible is illustrated by the following incident: although it was situated inside the designated flood risk zone (for 200-year floods), the municipality granted a homeowner a permit to expand his house. This house was destroyed by the 2014 flood. The 
Table 1 Barriers to adaptation in the two municipalities

\begin{tabular}{|c|c|c|}
\hline Barriers & Aurland municipality & Luster municipality \\
\hline Lack of resources & $\begin{array}{l}\text {-There is political support for the need for measures } \\
\text { and funds have been allocated to increase the level of } \\
\text { preparedness } \\
\text {-Need knowledge of potential risk to prioritise } \\
\text { resources between places } \\
\text {-Aurland has commissioned three reports from consul- } \\
\text { tancies, and established own weather stations and a } \\
\text { warning system in collaboration with StormGeo, a } \\
\text { private weather service provider }\end{array}$ & $\begin{array}{l}\text { - Political support for prioritising resources: 'Politicians under- } \\
\text { stand the conditions, they are living in this context' and 'Funding } \\
\text { external evaluation of the ground in advance of building develop- } \\
\text { ments is a given.' } \\
\text { - Risk of flooding in small streams are difficult to handle, as prior- } \\
\text { itisation between the streams are not possible: 'it is impossible to } \\
\text { know which small stream will flood. The margins are small, all it } \\
\text { takes is for instance a tree stuck underneath a bridge.' }\end{array}$ \\
\hline $\begin{array}{l}\text { Lack of localised } \\
\text { knowledge }\end{array}$ & $\begin{array}{l}\text {-Wind direction matters: 'The commissioned reports } \\
\text { show that the south-west weather hit here. This is } \\
\text { very useful knowledge. We use this when the weather } \\
\text { prognosis come. E.g. if there is forecasted easterly } \\
\text { weather and issued warning from NVE, we know } \\
\text { that it will not hit here. The variation is very local, } \\
\text { regional prognosis is of little value. We must know } \\
\text { the local variations and differences.' } \\
\text { - Climate projections of no use: 'The county climate } \\
\text { profile is not useful. E.g. it gives } 20-30 \% \text { increase in } \\
\text { slides in } 2100 . \text { However, our data show that we are at } \\
\text { this point now.' }\end{array}$ & $\begin{array}{l}\text { - Observed change: 'a lot more water within a shorter period of } \\
\text { time and very localised precipitation.' Yet: 'water is not a prob- } \\
\text { lem here'. But e.g. the storms in } 2011 \text { and in } 2012 \text { were } \\
\text {-Municipality have commissioned slide maps from NGI which } \\
\text { are 'more detailed and better than what we have received from } \\
\text { NVE.' }\end{array}$ \\
\hline $\begin{array}{l}\text { Lack of willing- } \\
\text { ness to adapt }\end{array}$ & $\begin{array}{l}\text { - Limits to preparedness: 'This was an extraordinary } \\
\text { event. We had } 230 \mathrm{~mm} \text { in } 3 \text { days. It is a lot. We don't } \\
\text { find similar numbers in the historic data' } \\
\text {-Technical fixes leads to complacency: 'Some think that } \\
\text { the municipality is secured after NVEs interventions } \\
\text { [in the river].' }\end{array}$ & $\begin{array}{l}\text { - Limits to preparedness: 'How on earth can we be prepared, other } \\
\text { than evacuation plan? The houses are on } 2 \mathrm{~m} \text { above sea level, and } \\
\text { there is little that we may do about it.' }\end{array}$ \\
\hline
\end{tabular}

municipality is not supposed to grant licences for new buildings or expansions within flood zones; according to Norwegian building regulation, if such a licence is granted, risk mitigation measures are required. This complacency hints about a sentiment that to anticipate an event of such a magnitude in near future is unmanageable, on a psychological level. Another hypothesis could also be that residents find it hard to comprehend what a $40 \%$ increase in flood risk by the end of the century means in the next decade.

There is also a perception of a high local adaptive capacity according to the informants. The event caused major material damage, but no lives were lost. With the new physical measures taken by NVE since the event, there is a general assumption that the valley is protected against similar events. However, one of our Aurland informants argued against this view that 'the municipality is secure after NVE's interventions' (informant 1). Luster municipality also experienced a devastating flood in 2018, but it did not affect the same community as the 2014 flood. However, the 2018 flood did destroy houses and properties in a regulated catchment, the Fortun valley, which is supposed to be protected from floods. Such an event is likely to shatter the complacency towards flood risk in regulated catchments that was expressed in the interviews (except with informant 1).

Regarding perceptions of the need to adapt, some informants assumed that it is not possible to avoid high-magnitude events; rather, such events will sometimes be outside the scope of what can be adapted to proactively. However, the informants did not say that more and better adaptation measures therefore were futile. Table 1 provides an overview of the barriers to adaptation in the two municipalities.

\section{A way forward for municipal adaptation to extreme events}

In the literature, there are few examples of proactive adaptation based on knowledge of future climate projections, and neither did we find any in this study. We have discussed how local governments responded to an extreme flood event in 2014 and their perceptions of the need to prepare for similar events in the future. We see that, in the aftermath of the event, the municipalities have been acting to restore the damages it caused. Some measures undertaken, such as building codes that mandate structures be built at elevated heights, also have the potential to support longer term preparedness for future events. We find three key barriers to adaptation in this context, which are a lack of resources, lack of locally relevant knowledge and lack of willingness to adapt. These barriers interlink and overlap and need to be addressed concertedly to support proactive adaptation. 
Lack of resources as a barrier to adaptation in municipalities pertains to administrative, fiscal and technical resources. A key aspect in the municipal context of limited resources is the prioritisation of resources. In this study, we found that there is political willingness to prioritise adaptation, including funding early warning system and commission external reports to increase knowledge of flood risks. Yet, there were concerns over securing enough resources to update the municipal spatial and zoning plans. Prioritisation of resources to adaptation may be supported by formal criteria on adaptation. As noted, the Norwegian government has defined high-end climate change projections as guidance for municipalities when they adapt to climate change. Yet, it is still unclear how municipalities should fund adaptation measures and what level of adaptation is to be expected from a municipality.

Dannevig et al. (2013) found that adaptation enters the agenda as a result of four factors. One of these is 'interaction with researchers', which involve co-production of knowledge. When knowledge about climate change impacts and adaptation measures is co-produced, there is a much greater chance for subsequent implementation than if the municipalities is just presented with climate change impact knowledge that are supposed to speak for itself (e.g. Dannevig et al. 2020; Bremer et al. 2019). Studies find that, although developing relevant scientific knowledge is important, 'its subsequent transfer to the decision-making realm in a format suitable for different end-users is critical' (McEvoy et al. 2010, p.793). In other words, it is not given that all and any scientific reporting may be 'translated' in such a way to be usable to decision makers at the point when they need to make decisions (e.g. Lemos 2015).

The Aurland case shows how long-term interaction with researchers at the NGI was important as the municipality started dealing with the consequences of an extreme event. This is a working relationship that has been established over many years. The emergency preparedness official in Aurland has acted as a 'boundary worker' (e.g. Clark et al. 2016; Dannevig et al. 2019), communicating and translating needs and knowledges between the municipality and researchers. However, despite knowledge of potential vulnerability based on the flood zone map, this still did not result in proactive measures against flooding in the Flåm valley. Nevertheless, increased involvement in knowledge production from stakeholders in affected communities could help shape the 'willingness to adapt', as such processes of co-production provide legitimacy and salience to the issue at hand (e.g. Clark et al 2016).

Access to and availability of scientific knowledge are no longer considered a barrier to adaptation in local governments (Aall et al. 2018; Porter et al. 2015), including in these two municipalities. Yet, there is no systematic way in which local knowledge of natural hazards, exposures and vulnerabilities is included in formal risk assessment exercises, such as production of flood maps or the natural hazard assessment done in spatial planning in the municipalities. However, the integration of local knowledge would certainly contribute to making scientific risk assessments and climate projections more locally relevant, in line with the recommendations from the IPCC's (2012) special report on extreme events, and thus help overcome the barrier 'lack of locally relevant knowledge'.

The event in 2014 was locally perceived as 'an extraordinary event', and the interviewees stated that they did not expect an event of similar magnitude to hit the region in the near future. However, in the context of high-end climate change modelling, the occurrence is not such an unexpected future event. It is a challenge that many models underestimate the impacts of extreme events (Schewe et al. 2019), and the regional climate profiles that are available to municipalities do not include extremes; instead, they give projections of climate trends.

As we see in our study, there is available regional climate information, but the municipalities are requesting knowledge that is relevant for their local context because there are great local variations, and perceptions of future risk of extreme events vary between the actors. However, an important challenge with climate projections and scenarios at high resolution is that locally relevant knowledge cannot be included in a typical approach.

Funding Open access funding provided by Western Norway Research Institute. This paper is part of a research project, Translating Weather Extremes into the Future-A Case for Norway (TWEX), financed by the Research Council of Norway (project no. 255037). We would like to thank all informants for their time. We would also like to thank Jana Sillmann for comments on earlier versions of this paper, as well as Eilif Ursin Reed for help with the figure, and two anonymous reviewers for helpful comments.

Open Access This article is licensed under a Creative Commons Attribution 4.0 International License, which permits use, sharing, adaptation, distribution and reproduction in any medium or format, as long as you give appropriate credit to the original author(s) and the source, provide a link to the Creative Commons licence, and indicate if changes were made. The images or other third party material in this article are included in the article's Creative Commons licence, unless indicated otherwise in a credit line to the material. If material is not included in the article's Creative Commons licence and your intended use is not permitted by statutory regulation or exceeds the permitted use, you will need to obtain permission directly from the copyright holder. To view a copy of this licence, visit http://creativecommons.org/licenses/by/4.0/.

\section{References}

Aall C, Aamaas B, Aaheim A, Dannevig H, Alnes K et al (2018) Oppdatering av kunnskap om konsekvenser av klimaendringer $\mathrm{i}$ Norge. CICERO Senter for klimaforskning, Oslo, Norway, p 176 
Adger WN, Barnett J, Chapin FS III, Ellemor H (2011) This Must Be the Place: underrepresentation of identity and meaning in climate change decision-making. Glob Environ Polit 11(2):1-25

Adger WN, Dessai S, Goulden M, Hulme M, Lorenzoni I et al (2009) Are there social limits to adaptation to climate change? Clim Change 93(3-4):335-354. https://doi.org/10.1007/ s10584-008-9520-Z

Aguiar FC, Bentz J, Silva JMN, Fonseca AL, Swart R et al (2018) Adaptation to climate change at local level in Europe: an overview. Environ Sci Policy 86:38-63. https://doi.org/10.1016/j. envsci.2018.04.010

Amundsen H, Berglund F, Westskog H (2010) Overcoming barriers to climate change adaptation-a question of multilevel governance? Eviron Plann C Gov Policy 28:276-289. https://doi.org/ $10.1068 / \mathrm{c} 0941$

Aurland Municipality (2015) Presentation of the flood in Aurland municipality 28.10.14, by Mayor Noralv Distad

Biesbroek GR, Klostermann JEM, Termeer C, Kabat P (2013) On the nature of barriers to climate change adaptation. Reg Environ Change 13:1119-1129. https://doi.org/10.1007/ s10113-013-0421-y

Burch S (2010) Transforming barriers into enablers of action on climate change: insights from three municipal case studies in British Columbia, Canada. Global Environmental Change-Human and Policy Dimensions 20:287-297. https://doi.org/10.1016/j. gloenvcha.2009.11.009

Bremer S, Wardekker A, Dessai S, Sobolowski S, Slaattelid R, van der Sluijs J (2019) Toward a multi-faceted conception of coproduction of climate services. Clim Serv 13:42-50. https:// doi.org/10.1016/j.cliser.2019.01.003

Clark WC, van Kerkhoff L, Lebel L, Gallopin GC (2016) Crafting usable knowledge for sustainable development. Proc Natl Acad Sci 113:4570-4578. https://doi.org/10.1073/pnas.1601266113

Crabbé P, Robin M (2006) Institutional adaptation of water resource infrastructures to climate change in Eastern Ontario. Clim Change 78:103-133. https://doi.org/10.1007/ s10584-006-9087-5

Dannevig H, Hovelsrud GK, Hermansen EAT, Karlsson M (2020) Culturally sensitive boundary work: A framework for linking knowledge to climate action. Environ Sci Policy 112:405-413. https://doi.org/10.1016/j.envsci.2020.07.002

Dannevig H, Aall C (2015) The regional level as boundary organization? An analysis of climate change adaptation governance in Norway. Environ Sci Policy 54:168-175. https://doi.org/10. 1016/j.envsci.2015.07.001

Dannevig H, Groven K, Aall C (2016) Oktoberflaumen på Vestlandet i 2014. Norges vassdrags- og energidirektorat, Oslo

Dannevig H, Groven K, Hovelsrud GK, Lundberg AK, Bellerby RG et al (2019) A framework for agenda-setting ocean acidification through boundary work. Environ Sci Policy 95:28-37. https:// doi.org/10.1016/j.envsci.2019.02.001

Dannevig H, Hovelsrud GK (2016) Understanding the need for adaptation in a natural resource dependent community in Northern Norway: issue salience, knowledge and values. Clim Change 135:261-275. https://doi.org/10.1007/s10584-015-1557-1

Dannevig H, Hovelsrud GK, Husabo IA (2013) Driving the agenda for climate change adaptation in Norwegian municipalities. Environment and Planning C-Government and Policy 31:490505. https://doi.org/10.1068/c1152

Dilling L, Lemos MC (2011) Creating usable science: Opportunities and constraints for climate knowledge use and their implications for science policy. Glob Environ Chang 21:680-689. https://doi. org/10.1016/j.gloenvcha.2010.11.006

Dottori F, Szewczyk W, Ciscar J-C, Zhao F, Alfieri L et al (2018) Increased human and economic losses from river flooding with anthropogenic warming. Nat Clim Chang 8:781-786. https:// doi.org/10.1038/s41558-018-0257-z

Eisenack K, Moser SC, Hoffmann E, Klein RJT, Oberlack C et al (2014) Explaining and overcoming barriers to climate change adaptation. Nat Clim Chang 4:867-872. https://doi.org/10.1038/ nclimate 2350

Falleth E, Hanssen GS (2012) Medvirkning i planlegging. In: Aarsæther N, Falleth E, Nyseth T, Kristiansen R (eds) Utfordringer for norsk planlegging. Kunnskap. Bærekraft. Demokrati, Cappelen Damm, Kristiansand, pp 187-202

Flyen C, Hauge ÅL, Almås A-J, Godbolt ÅL (2018) Municipal collaborative planning boosting climate resilience in the built environment. Int J Disaster Resil Built Environ 9:58-69. https://doi. org/10.1108/IJDRBE-10-2016-0042

Füssel H-M (2007) Adaptation planning for climate change: concepts, assessment approaches, and key lessons. Sustain Sci 2:265-275. https://doi.org/10.1007/s11625-007-0032-y

Gifford R, Kormos C, McIntyre A (2011) Behavioral dimensions of climate change: drivers, responses, barriers, and interventions. Wiley Interdiscip Rev Clim Change 2:801-827. https://doi.org/10.1002/ wcc. 143

Hanssen-Bauer I, Drange H, Førland EJ, Roald LA, Børsheim KY et al (2009) Klima i Norge 2100. Bakgrunnsmateriale til NOU Klimatilpassing, Norsk klimasenter, Oslo

Hanssen-Bauer I, Førland EJ, Haddeland I, Hisdal H, Mayer S et al (2015) Klima i Norge 2100. Kunnskapsgrunnlag for klimatilpasning oppdatert i 2015. Oslo: Norsk Klimaservicesenter. NCCS report no. $2 / 2015.204 \mathrm{~s}$

Hauge ÅL, Hanssen GS, Flyen C (2018) Multilevel networks for climate change adaptation - what works? Int J Clim Chang Strateg Manag. https://doi.org/10.1108/IJCCSM-10-2017-0194

Hazeleger W, van den Hurk BJJM, Min E, van Oldenborgh GJ, Petersen AC et al (2015) Tales of future weather. Nat Clim Change 5:107113. https://doi.org/10.1038/NCLIMATE2450

Hovelsrud GK, Dannevig H, West JJ, Amundsen H (2010) Adaptation in fisheries and municipalities: three communities in northern Norway. In: Hovelsrud GK, Smit B (eds) Community adaptation and vulnerability in arctic regions. Springer, Dordrecht, pp 23-62

IPCC (2012) Managing the Risks of extreme events and disasters to advance climate change adaptation. In: Field CB, Barros V, Stocker TF, Qin D, Dokken DJ et al (eds) A special report of working groups I and II of the intergovernmental panel on climate change. Cambridge University Press, Cambridge, UK, and New York

IPCC (2014a) Climate change 2014: impacts, adaptation, and vulnerability. In: Field CB, Barros VR, Dokken DJ, Mach KJ, Mastrandrea MD et al (eds) Part A: global and sectoral aspects. Contribution of working group II to the fifth assessment report of the intergovernmental panel on climate change. Cambridge University Press, Cambridge, UK, and New York

IPCC (2014b) Climate change 2014: impacts, adaptation, and vulnerability. In: Barros VR, Field CB, Dokken DJ, Mastrandrea MD, Mach KJ et al (eds) Part B: regional aspects. Contribution of Working Group II to the Fifth Assessment Report of the Intergovernmental Panel on Climate Change. Cambridge University Press, Cambridge, UK, and New York

Junker E (2015) Kommunens kontroll med eksterne utredninger av fare i planlegging og byggesak. Kart og Plan 75:51-63 
Klein RJT, Midgley GF, Preston BL, Alam M, Berkhout FGH et al (2014) Adaptation opportunities, constraints, and limits. In: Field CB, Barros VR, Dokken DJ, Mach KJ, Mastrandrea MD et al (eds) Climate change 2014: impacts, adaptation, and vulnerability. Part A: global and sectoral aspects. Contribution of working group II to the fifth assessment report of the intergovernmental panel on climate change. Cambridge University Press, Cambridge, UK, and New York, pp 899-943.

Klenk N, Fiume A, Meehan K, Gibbes C (2017) Local knowledge in climate adaptation research: moving knowledge frameworks from extraction to co-production. Wiley Interdiscip. Rev Clim Chang 8:475. https://doi.org/10.1002/wcc.475

Kirchhoff CJ, Carmen Lemos M, Dessai S (2013) Actionable knowledge for environmental decision making: broadening the usability of climate science. Annu Rev Environ Resour 38:393-414. https:// doi.org/10.1146/annurev-environ-022112-112828

Langsholt E, Roald LA, Holmqvist E, Fleig A (2015) Flommen på Vestlandet oktober 2014. NVE Rapport nr, Oslo, pp 11-2015

Lemos MC (2015) Usable climate knowledge for adaptive and comanaged water governance. Curr Opin Environ Sustain 12:48-52. https://doi.org/10.1016/j.cosust.2014.09.005

Luster Municipality (2014) Overordna heilskapleg ROS-analyse for Luster kommune

McEvoy D, Matczak P, Banaszak I, Chorynski A (2010) Framing adaptation to climate-related extreme events. Mitig Adapt Strateg Glob Change 15:779-795. https://doi.org/10.1007/s11027-010-9233-2

Measham TG, Preston BL, Smith TF, Brooke C, Gorddard R et al (2011) Adapting to climate change through local municipal planning: barriers and challenges. Mitig Adapt Strateg Glob Change 16(8):889-909. https://doi.org/10.1007/s11027-011-9301-2

MoE (2010) Adapting to a changing climate Norway's vulnerability and the need to adapt to the impacts of climate change. Official Norwegian Reports NOU 2010: 10. Ministry of Environment, Oslo

Moser SC, Ekstrom JA (2010) A framework to diagnose barriers to climate change adaptation. Proc Nat Acad Sci USA 107(51):2202622031. https://doi.org/10.1073/pnas.1007887107

Multiconsult (2015). Flomdemping for Flåmselvi. Notat 128522-RiVass-NOT1. Multiconsult, Oslo

Multiconsult (2016) Flomdempingstiltak for vern av liv og helse i Flåm. Aurland kommune, Multiconsult, Oslo

Multiconsult (2018) Verdien av vassdragsreguleringer for reduksjon av flomskade. 130698-RIVass-RAP-001. Multiconsult, Oslo
NGI (2016) Erosjonsvurdering, faresoner for erosjon, Flåmselvi

NGI (2017) Klimatilpasning og endringer i kommunal risiko- håndtering/beredskap. Instrumentering, prosessforståelse som grunnlag for tidlig varsling. Lokal varsling av skred og flom i risikoutsatte områder. Kommunal beredskap basert på terskelverdier, lokale analyser og overvåking av risikoutsatte områder. NGI-rapport. Rapport 20150084-05-R. Norges Geotekniske Institutt, Oslo

Norconsult (2016) Flomsonekart i Flåm

Porter JJ, Demeritt D, Dessai S (2015) The right stuff? Informing adaptation to climate change in British Local Government. Glob Environ Change 35:411-422. https://doi.org/10.1016/j.gloenvcha. 2015.10.004

Schewe J, Gosling SN, Reyer C, Zhao F, Ciais P et al (2019) Stateof-the-art global models underestimate impacts from climate extremes. Nat Commun 10(1):1005. https://doi.org/10.1038/ s41467-019-08745-6

Shepherd TG, Boyd E, Calel RA, Chapman SC, Dessai D et al (2018) Storylines: an alternative approach to representing uncertainty in physical aspects of climate change. Clim Change 151:555-571. https://doi.org/10.1007/s10584-018-2317-9

Sillmann J, Shepherd T, van den Hurk B, Hazeleger W, Martius-Rompainen $\mathrm{O}$ et al (2019) Physical modeling supporting a storyline approach. CICERO Policy Note 2019:01

Tschakert P, Barnett J, Ellis N, Lawrence C, Tuana N et al (2017) Climate change and loss, as if people mattered: values, places, and experiences. WIREs Clim Change e476. https://doi.org/10. 1002/wcc. 476

Valved AS, Olsen A-M (eds) (2014) Nedbørrapport. Nord-Rogaland, Hordaland og Sogn og Fjordane 26.-29. okt. 2014, Bergen: Meteorologisk institutt. Rapport 18/2014

Whan K, Sillmann J, Schaller N, Haarsma R (2020) Future changes in atmospheric rivers and extreme precipitation in Norway. Clim Dyn 54:2071-2084. https://doi.org/10.1007/s00382-019-05099-Z

Willner SN, Levermann A, Zhao F, Frieler K (2018) Adaptation required to preserve future high-end river flood risk at present levels. Sci Adv 4(1):eaao1914. https://doi.org/10.1126/sciadv. aao1914

Publisher's note Springer Nature remains neutral with regard to jurisdictional claims in published maps and institutional affiliations. 